\title{
Comparison of clonidine and fentanyl as an adjuvant to intrathecal bupivacaine for spinal anaesthesia and postoperative analgesia in patients undergoing caesarian section
}

\author{
Ramchandra Vinayak Shidhay ${ }^{I^{*}}$, Bhavini Bhushan Shah ${ }^{2}$, Smita Suresh Joshi ${ }^{3}$, Shrikrishna Govind \\ Deogaonkar, Abhishek P Bhuva ${ }^{5}$ \\ Professor ${ }^{1}$, Associate Professor ${ }^{4}$, Resident $^{5}$, Department of Anaesthesiology and Critical Care, Pravara \\ Institute of Medical Sciences, Loni 413736, India. Assistant Professor ${ }^{2}$, Professor ${ }^{3}$, Department of \\ Anaesthesiology and Critical Care, Dr. D.Y. Patil Medical College Pimpri, Pune 411018, India.
}

*Corresponding author: rvshidhaye@gmail.com

\begin{abstract}
Background
Fentanyl and clonidine both prolong sensory and motor block of spinal anaesthesia and duration of postoperative analgesia when used as an adjuvant to intrathecal bupivacaine. Lack of studies that directly compare them regarding their efficacy prompted us to compare both drugs as an adjuvant to intrathecal bupivacaine for spinal anaesthesia and postoperative analgesia in patients undergoing caesarian section.
\end{abstract}

\begin{abstract}
Methods and Material
In a prospective, randomized, study forty parturients between 18 to 35 years of age, of ASA grade I or II, awaiting caesarian section were randomly distributed into two equal groups. Patients were given $2.0 \mathrm{ml}$ of hyperbaric bupivacaine $0.5 \%$ with either $60 \mu \mathrm{g}$ of clonidine or $25 \mu \mathrm{g}$ of fentanyl intrathecally. Duration of effective analgesia (primary outcome measure), onset peak and duration of sensory and motor blockade, level of sedation, maternal haemodynamic parameters and foetal parameters (secondary outcome measures)were compared.
\end{abstract}

\section{Results}

Both groups were comparable with respect to demographic profile, onset, peak and duration of sensory and motor block and overall haemodynamic stability. Duration of analgesia was

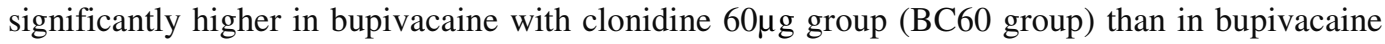
with fentanyl $25 \mu \mathrm{g}$ group (BF25 group). Sedation was more prevalent in BC60 group.

\section{Conclusion}

Intrathecal addition of $25 \mu \mathrm{g}$ fentanyl to bupivacaine provides good analgesia with less sedation and is a better option when sedation is not desirable. However intrathecal addition of $60 \mu \mathrm{g}$ clonidine to bupivacaine provides longer duration of postoperative analgesia than $25 \mu \mathrm{g}$ of fentanyl and is a preferred option when sedation is acceptable or required.

Key words: intrathecal; clonidine; bupivacaine; postoperative analgesia; spinal anaesthesia

\section{Introduction}

Spinal anaesthesia and postoperative analgesia can be prolonged by using adjuvants to local anaesthetics like adrenaline, midazolam, opioids, neostigmine and clonidine $e^{1,2-6}$.Administration of opioids as adjuvants to local anaesthetics intrathecally results in both synergistic and multimodal analgesia ${ }^{7}$. The successful use of intrathecal morphine in human beings was first described by Wang et $\mathrm{al}^{8}$ in 1979 . Since then almost all opioids have been used via this route. Fentanyl citrate, a $\mu-1$ and $\mu-2$ agonist is a very potent drug because of its high lipophilicity. It is preferred as an adjuvant in spinal anaesthesia because of its rapid onset and short duration of action with lesser incidence of respiratory depression ${ }^{2,9}$. However pruritus, nausea, vomiting, activation of herpes labialis, urinary retention and late and especially unpredictable, respiratory depression of other opioids have directed pain research towards non-opioids ${ }^{10}$. Clinical studies 
have suggested that intrathecal clonidine prolongs sensory and motor block of spinal anaesthesia. It decreases local anaesthetic requirements ${ }^{11}$, and provides prolonged postoperative analgesia ${ }^{2-6}, 12-$ ${ }^{13}$. Other beneficial effects are antiemesis, reduced post spinal shivering, anxiolysis and sedation. Unlike spinal opioids, clonidine does not produce pruritus or respiratory depression. In this study we have compared intrathecal clonidine with fentanyl in regard to their efficacy and safety as an adjuvant to intrathecal bupivacaine for spinal anaesthesia and postoperative analgesia in patients undergoing caesarian section.

\section{Method}

A prospective, randomized, study design with two parallel groups was used. After prior approval from Institutional Ethics Committee, study was conducted on 40 parturients of age group between 18 - 35 years and of ASA grade I or II booked for elective as well as emergency Lower Segment Caesarian Section. Informed consent was obtained from all the parturients. Exclusion criteria were complicated pregnancy including pregnancyinduced hypertension, placenta praevia, abruptio placentae, severe systemic disorders like diabetes mellitus, hypertension, heart disease changing ASA grade to more than II, allergy to bupivacaine, fentanyl or clonidine and all known contraindications for spinal anaesthesia, such as spine deformity, increased intracranial pressure, neurological disorders, haemorrhagic diathesis, or infection at the puncture site. Parturients were randomly divided by blocked randomization method into two groups of 20 patients each and randomization was concealed.

\section{GROUP BF $25(\mathrm{n}=20)$}

In this group, each patient was given $2.0 \mathrm{ml}(10$ $\mathrm{mg}$ ) of hyperbaric bupivacaine $0.5 \%$ with $25 \mu \mathrm{g}$ of fentanyl, intrathecally.

\section{GROUP BC $60(n=20)$}

In this group, each patient was given $2.0 \mathrm{ml}(10 \mathrm{mg})$ of hyperbaric bupivacaine $0.5 \%$ with $60 \mu \mathrm{g}$ of clonidine, intrathecally.

The sample size could not be calculated before the start of the study due to paucity of similar studies. Post-hoc power analysis was carried out keeping its limitations in mind for duration of effective analgesia measured by time in minutes for requirement of rescue analgesia. This study had $99.53 \%$ power to detect effect size of 180.95 minutes between two groups assuming alpha error 0.05(two-sided). Sedatives and hypnotics were avoided in premedication, as well as intraoperatively. All these patients were premedicated with intravenous ondansetron $(4 \mathrm{mg})$ and routine acid aspiration prophylaxis per orally. Patients were preloaded with Ringer Lactate (RL) $10-15 \mathrm{ml} / \mathrm{kg}$. Pre-operative parameters like pulse rate, oxygen saturation and blood pressure were recorded. Spinal anaesthesia was given with $25 \mathrm{G}$ Quincke needle in sitting position with aseptic precautions. Depending upon the groups, respective agents were injected intrathecally. Each group had a total volume of $2.5 \mathrm{ml}$ made by addition of normal saline. Both the patient and anaesthesiologist were blinded to the study solutions. Syringes were prepared just before the spinal injection ensuring the volumes of $2.5 \mathrm{ml}$ by a third person knowing the code to blind the anaesthesiologist administering the drug and later on making the observations. Pulse and blood pressure were measured every 5 minutes for first 30 minutes and thereafter every 10 minutes. Number of occasions for pulse rate and blood pressure variations more than $20 \%$ of baseline were noted in both groups. Bradycardia was treated with i.v. atropine $0.6 \mathrm{mg}$ if persistent for a long time and was symptomatic. Sensory block was tested by pinprick method. Degree of motor blockade was assessed by modified Bromage scale used by Breen et $\mathrm{al}^{14}$. Observations were made at $\mathrm{T}_{0}=$ Time of spinal anaesthesia, $\mathrm{T}_{1}=$ Time of onset of sensory block, $\mathrm{T}_{2}=$ Time of onset of motor block, $\mathrm{T}_{3}=$ Time of peak sensory block, $\mathrm{T}_{4}=$ Time to two segment regression of sensory level, $\mathrm{T}_{5}=$ Time of wearing off of motor block, $\mathrm{T}_{6}=$ Time to first dose of post-operative rescue analgesia. Apgar score of the newborn was monitored at 1, 5, and 10 minutes. In the intra operative period, patient was closely monitored for pulse rate, $\mathrm{SpO}_{2}$, blood pressure and blood loss. Oxytocin 10U was added to RL infusion after delivery of the anterior shoulder. Any side effects such as nausea, vomiting, pain, shivering, pruritus, sedation, hypotension, bradycardia, and respiratory discomfort were noted. Patients were assessed for degree of sedation and scoring was done with Campbell Sedation Score as 1) wide awake 2) 
awake and comfortable 3) drowsy and difficult to arouse 4) not rousable. Residual sensory blockade was monitored and its wearing off time was noted (when sensation to pin-prick gets 2 dermatomal segments regression). Residual motor blockade was monitored and its wearing off time was noted when patient started to lift legs against gravity. Patients were monitored for degree of pain with the Visual Analogue Scale (VAS). Postoperative rescue analgesia (intramuscular diclofenac $75 \mathrm{mg}$ ) was given when the VAS score was $>7$ and the time of injection of first analgesic drug was noted. This was taken as the time of wearing off of analgesia.

Statistical analysis was carried out with Stata 10. Demographic characteristics, haemodynamic parameters, onset, peak and duration of sensory and motor block and duration of postoperative analgesia, level of sedation and foetal parameters were compared between two groups and data was analyzed. For continuous variables descriptive statistics (mean and standard deviations) were computed. Comparison of means in group BF 25 and group $\mathrm{BC} 60$ was done using unpaired ttest. For categorical data chi-square test was applied. $\mathrm{P}<0.05$ was considered significant.

\section{Results}

Both groups were comparable with respect to their demographic profile as shown in Table I.

There was no significant difference in them regarding age, ASA status, height, weight, parity, duration of pregnancy and duration of labour

Table 1 Demographic characteristics

\begin{tabular}{|c|c|c|c|c|}
\hline \multirow{2}{*}{\multicolumn{2}{|c|}{ Characteristics }} & $\begin{array}{l}\text { BF25 Group } \\
(n=20)\end{array}$ & $\begin{array}{l}\text { BC60 Group } \\
(n=20)\end{array}$ & $P$ value \\
\hline & & $\begin{array}{l}\text { Mean } \pm \text { SD } \\
\text { (Range) }\end{array}$ & $\begin{array}{l}\text { Mean } \pm \text { SD } \\
\text { (Range) }\end{array}$ & \\
\hline \multicolumn{2}{|c|}{ Age in years } & $\begin{array}{l}23.1 \pm 2.55 \\
(19-28)\end{array}$ & $\begin{array}{l}24.7 \pm 3.15^{*} \\
(19-30)\end{array}$ & 0.09 \\
\hline \multicolumn{2}{|c|}{ Height in $\mathrm{cm}$. } & $\begin{array}{l}153.65 \pm 5.21 \\
(146-167)\end{array}$ & $\begin{array}{l}153.25 \pm \\
6.09^{*} \\
(142-167)\end{array}$ & 0.82 \\
\hline \multicolumn{2}{|c|}{ Weight in kg } & $\begin{array}{l}57.6 \pm 7.92 \\
(40-72)\end{array}$ & $\begin{array}{l}59.65 \pm 8.73 \\
(42-78)^{*}\end{array}$ & 0.44 \\
\hline \multicolumn{2}{|c|}{$\begin{array}{l}\text { Duration of pregnancy } \\
\text { in weeks }\end{array}$} & $\begin{array}{l}38.72 \pm 1.36 \\
(36-40.3)\end{array}$ & $\begin{array}{l}38.68 \pm 1.77 \\
(34.6-42)^{*}\end{array}$ & 0.94 \\
\hline \multicolumn{2}{|c|}{$\begin{array}{l}\text { Duration of labour in } \\
\text { hours }\end{array}$} & $\begin{array}{l}3.65 \pm 2.87 \\
(1-10)\end{array}$ & $\begin{array}{l}4.55 \pm 4.01 \\
(1-18)^{*}\end{array}$ & 0.42 \\
\hline \multirow{3}{*}{ Parity } & Primipara & $7 \quad *$ & $6 *$ & \multirow{3}{*}{0.15} \\
\hline & Second para & 11 & & \\
\hline & Multipara & 2 & 7 * & \\
\hline
\end{tabular}

BF 25 Group: Intrathecal $2.0 \mathrm{ml}$ of hyperbaric bupivacaine $0.5 \%$ with $25 \mu \mathrm{g}$ of fentanyl.

BC60 Group: Intrathecal $2.0 \mathrm{ml}$ of hyperbaric bupivacaine $0.5 \%$ with $60 \mu \mathrm{g}$ of clonidine.

* p-value $>0.05$

They were also comparable with respect to their baseline haemodynamic parameters like pulse rate $(87.85 \pm 8.55: 89 \pm 12.08)$, systolic blood pressure (119.15 \pm 8.53 : 119.85 \pm 7.09$)$, diastolic blood pressure (74.9 \pm 9.71 : $77.55 \pm 8.09$ ). Patients from both groups were comparable with haemodynamic parameters as shown in Table 2. No significant difference was found in them regarding average pulse rate ( $87.84 \pm 12.54$ : $88.41 \pm 13.60)$, average systolic blood pressure (112.29 \pm 12.28 :111.05 \pm 10.26 ), average diastolic blood pressure (64.43 \pm 8.71: $63.25 \pm 9.38$ ). No significant difference was found regarding pulse variation (21:28) and incidence of hypotension (11: 17). Bradycardia $<60$ beats/minute was observed only in two patients and both belonged to BC 60 group. Only one of them showed pulse rate drop up to the level of 50 beats/minutes needing intervention and responded well to i.v. atropine $0.6 \mathrm{mg}$.

Table 2 Comparison of maternal haemodynamic parameters

\begin{tabular}{|c|c|c|c|}
\hline \multirow[t]{2}{*}{ Parameter } & $\begin{array}{l}\text { BF25 group } \\
(n=20)\end{array}$ & $\begin{array}{l}\text { BC60 group } \\
(n=20)\end{array}$ & \multirow{2}{*}{$\begin{array}{l}p \\
\text { value }\end{array}$} \\
\hline & Mean \pm SD & Mean \pm SD & \\
\hline $\begin{array}{l}\text { Baseline pulse rate per } \\
\text { minute }\end{array}$ & $87.85 \pm 8.55$ & $89 \pm 12.08$ & 0.73 \\
\hline $\begin{array}{l}\text { Baseline systolic blood } \\
\text { pressure } \mathrm{mmHg}\end{array}$ & $119.15 \pm 8.53$ & $119.85 \pm 7.09$ & 0.78 \\
\hline $\begin{array}{l}\text { Baseline diastolic blood } \\
\text { pressure } \mathrm{mmHg}\end{array}$ & $74.9 \pm 9.71$ & $77.55 \pm 8.09$ & 0.35 \\
\hline $\begin{array}{l}\text { Average pulse rate per } \\
\text { minute }\end{array}$ & $87.84 \pm 12.54$ & $88.41 \pm 3.60$ & 0.89 \\
\hline Average systolic BP mmHg & $\begin{array}{l}112.29 \pm 12.2 \\
8\end{array}$ & $111.05 \pm 10.26$ & 0.73 \\
\hline Average diastolic $\mathrm{BP} \mathrm{mmHg}$ & $\begin{array}{ll}64.43 \quad \pm \\
8.71 & \end{array}$ & $63.25 \pm 9.38$ & 0.68 \\
\hline \multicolumn{4}{|l|}{ Haemodynamic variability } \\
\hline $\begin{array}{l}\text { Number of occasions of } \\
\text { pulse rate fall< } 80 \% \text { of } \\
\text { baseline }\end{array}$ & 11 & 12 & \multirow{4}{*}{$\begin{array}{l}p \\
\text { Value } \\
0.13\end{array}$} \\
\hline $\begin{array}{l}\text { Number of occasions of } \\
\text { pulse rate rise }>120 \% \text { of } \\
\text { baseline }\end{array}$ & 10 & 16 & \\
\hline $\begin{array}{l}\text { Number of occasions of fall } \\
\text { in } \mathrm{BP} \\
<80 \% \text { of baseline }\end{array}$ & 8 & 17 & \\
\hline $\begin{array}{l}\text { Number of occasions of rise } \\
\text { in } \mathrm{BP} \\
>120 \% \text { of baseline }\end{array}$ & 3 & 0 & \\
\hline $\begin{array}{l}\text { Total number of occasions of } \\
\text { haemodynamic variability }\end{array}$ & 32 & 45 & 77 \\
\hline
\end{tabular}


Table 3 compares onset, peak and duration of sensory and motor block and duration of postoperative analgesia. There was no difference in onset of sensory block $(0.90 \pm 0.21: 0.91 \pm 0.17$ min ) ( $>0.05)$, onset of motor block $(1.59 \pm 0$ $.48: 1.71 \pm 0.51 \mathrm{~min})(\mathrm{p}>0.05)$, onset of peak sensory block $(7.55 \pm 0.94: 7.54 \pm 1.80 \mathrm{~min})(\mathrm{p}>$ $0.05)$, two segment regression of sensory block $(131 \pm 14.83: 135.2 \pm 12.45 \mathrm{~min})(\mathrm{p}>0.05)$ and wearing of motor block (189.5 \pm 18.06 : $182.1 \pm 10.08 \mathrm{~min})(\mathrm{p}>0.05)$. Duration of analgesia was significantly higher in BC60 group $(598.7 \pm 140.47 \mathrm{~min})$ than in BF25 (417.75 $\pm 108.76)$ group. $(\mathrm{p}<0.01)$.

Table 3 Comparison of sensory, motor blockade and duration of analgesia

\begin{tabular}{|c|c|c|c|}
\hline \multirow[t]{2}{*}{ Parameter } & $\begin{array}{l}\text { BF25 Group } \\
(n=20)\end{array}$ & $\begin{array}{l}\text { BC60 Group } \\
(n=20)\end{array}$ & $p$ value \\
\hline & Mean \pm SD & Mean \pm SD & \\
\hline $\begin{array}{l}\text { Time in minutes for } \\
\text { onset of sensory } \\
\text { blockade }\end{array}$ & $0.90 \pm 0.21$ & $0.91 \pm 0.17^{\star}$ & 0.87 \\
\hline $\begin{array}{l}\text { Time in minutes for } \\
\text { onset of motor } \\
\text { blockade }\end{array}$ & $1.59 \pm 0.48$ & $1.71 \pm 0.51^{*}$ & 0.44 \\
\hline $\begin{array}{l}\text { Time in minutes for } \\
\text { peak of sensory } \\
\text { blockade }\end{array}$ & $7.55 \pm 0.94$ & $7.54 \pm 1.80^{*}$ & 0.98 \\
\hline $\begin{array}{l}\text { Two segment } \\
\text { regression time in } \\
\text { minutes for sensory } \\
\text { blockade }\end{array}$ & $131 \pm 14.83$ & $135.2 \pm 12.45^{*}$ & 0.34 \\
\hline $\begin{array}{l}\text { Time in minutes for } \\
\text { wearing off of motor } \\
\text { block }\end{array}$ & $189.5 \pm 18.06$ & $182.1 \pm 10.08^{*}$ & 0.12 \\
\hline $\begin{array}{l}\text { Time in minutes for } \\
\text { first rescue analgesia }\end{array}$ & $\begin{array}{l}417.75 \pm \\
108.76\end{array}$ & $598.7 \pm 140.47^{* \text { * }}$ & 0.0001 \\
\hline
\end{tabular}

Sedation score 4 was observed in none of the patients from both groups as per shown in Table 4. More patients from group BC 60 showed sedation score of 2 or 3 implying more sedation with clonidine than with fentanyl. $(\mathrm{p}<0.01)$.
Table 4 Sedation score

(Number of patients having sedation score in each group)

\begin{tabular}{|l|l|l|l|l|}
\hline \multicolumn{2}{|l|}{ Sedation score } & Group BF 25 & $\begin{array}{l}\text { Group BC } \\
60\end{array}$ & Total \\
\hline 1 & Wide awake & $19(95 \%)$ & $1(5 \%)$ & 20 \\
\hline 2 & Awake and comfortable & $1(5 \%)$ & $14(70 \%)$ & 15 \\
\hline 3 & $\begin{array}{l}\text { Drowsy and difficult to } \\
\text { arouse }\end{array}$ & 0 & $5(25 \%)$ & 5 \\
\hline 4 & Not rousable & 0 & 0 & 0 \\
\hline \multicolumn{2}{|l|}{ Total } & 20 & 20 & 40 \\
\hline \multicolumn{2}{|l|}{ Pearson chi2(2) $=32.4500 \mathrm{Pr}=0.000 p<0.01$} \\
\hline
\end{tabular}

The other side effects observed for were not seen in both groups.

Table 5 shows overall foetal wellbeing in both groups. APGAR scores at one minute, 5 minutes and 10 minutes after birth were comparable in both groups. $(p>0.05)$

Table 5 Comparison of foetal parameters

\begin{tabular}{|l|l|l|l|}
\hline Characteristics & $\begin{array}{l}\text { BF25 Group } \\
(\mathrm{n}=20)\end{array}$ & $\begin{array}{l}\text { BC60 Group } \\
(\mathrm{n}=20)\end{array}$ & $\begin{array}{l}\mathrm{p} \\
\text { value }\end{array}$ \\
\cline { 2 - 4 } & Mean \pm SD & Mean \pm SD & \\
\hline $\begin{array}{l}\text { APGAR Score at } 1 \\
\text { minute }\end{array}$ & $7.2 \pm 0.41$ & $7.35 \pm 0.49$ * & 0.30 \\
\hline $\begin{array}{l}\text { APGAR Score at } 5 \\
\text { minute }\end{array}$ & $8.4 \pm 0.50$ & $8.35 \pm 0.49$ * & 0.75 \\
\hline $\begin{array}{l}\text { APGAR Score at } 10 \\
\text { minutes }\end{array}$ & $9.5 \pm 0.51$ & $9.4 \pm 0.50^{*}$ & 0.54 \\
\hline${ }^{*} p$-value $>0.05$ & \multicolumn{3}{|l}{} \\
\hline
\end{tabular}

\section{Discussion}

Both fentanyl and clonidine if used in low doses are safe and prolong postoperative analgesia of intrathecal bupivacaine. Thorough literature search revealed paucity of studies directly comparing these two drugs for their efficacy and safety. Present study was designed to directly compare these two drugs. To compare the efficacy we used the duration of effective analgesia measured by time in minutes for requirement of rescue analgesia. In consistency to results of several other studies ${ }^{2,4-6,15,16}$ we found both drugs to be effective as adjuvants to intrathecal bupivacaine prolonging the duration of analgesia. Duration of analgesia was significantly higher in BC60 group $(598.7 \pm 140.47 \mathrm{~min})$ than in BF25 (417.75 $\pm 108.76)$ group, $(\mathrm{p}<0.01)$. Prolonged duration of analgesia due to fentanyl in our study was different to other studies ${ }^{15,16}$. Similarly prolonged 
duration of analgesia due to clonidine in our study was also different to other studies. ${ }^{2,}{ }^{4-6}$.This was expected considering the different doses of clonidine, fentanyl or bupivacaine used. A small dose of intrathecal clonidine as well as fentanyl is not usually associated with systemic side effects such as bradycardia, hypotension, or sedation. The overall haemodynamic stability observed in both groups throughout the surgical procedure in our study confirms to this. Only two patients had significant bradycardia one of which got corrected on its own. Bradycardia requiring treatment was observed only in one patient who responded well to i.v.atropine $0.6 \mathrm{mg}$. Kothari $\mathrm{N}$ et $\mathrm{al}^{5}$ found the incidence of both hypotension and bradycardia more in bupivacaine group than in bupivacaine with clonidine group. Bajwa $\mathrm{SJ}^{6}$ who used $9 \mathrm{mg}$ of bupivacaine also did not observe bradycardia by addition of clonidine even up to $45 \mu \mathrm{g}$. Shah $\mathrm{BB}^{13}$ and Sethi $\mathrm{BS}^{12}$ who used $1 \mathrm{mcg} / \mathrm{kg}$ of intrathecal clonidine for non-obstetric surgeries had also very few incidences of hypotension and bradycardia requiring intervention. Biswas et al ${ }^{15}$ and Agrawal $A$ et $\mathrm{al}^{16}$ observed similar haemodynamic stability with $12.5 \mu \mathrm{g}$ and $25 \mu \mathrm{g}$ of intrathecal fentanyl. Our findings regarding haemodynamic stability with use of fentanyl were in agreement to their findings and our findings with use of clonidine were in agreement to several other studies ${ }^{2,4-6}$.We could not appreciate any difference in both groups regarding onset, peak and duration of sensory and motor block. We found duration of analgesia significantly higher in BC60 group than in BF25 group $(\mathrm{p}<0.05)$. This implies that both fentanyl and clonidine prolong the duration of postoperative analgesia and it is more with clonidine than fentanyl. We observed a similar difference in sedation scores. We observed more sedation scores in BC 60 group than in $\mathrm{BF}$ 25 group $(\mathrm{p}<0.05)$. Kothari $\mathrm{N}$ et $\mathrm{al}^{5}$ also found 35 to $45 \%$ of patients drowsy by addition of $50 \mu \mathrm{g}$ of clonidine to bupivacaine; but Bajwa $\mathrm{SJ}$ et $\mathrm{al}^{6}$ did not find any sedation by addition of up to $45 \mu \mathrm{g}$ of clonidine to bupivacaine. Thus the sedation with clonidine is dose dependent. In our study we could not observe sedation with intrathecal fentanyl added to bupivacaine similar to Biswas $\mathrm{BN}$ et $\mathrm{al}^{15}$ Dahlgren $\mathrm{G}$ et $\mathrm{al}^{19}$ and Hunt $\mathrm{CO}$ et $\mathrm{al}^{20}$. In conclusion, intrathecal addition of $60 \mu \mathrm{g}$ clonidine to bupivacaine gives longer duration of postoperative analgesia than $25 \mu \mathrm{g}$ of fentanyl but with higher degree of sedation. Fairly good analgesia is observed with less sedation with $25 \mu \mathrm{g}$ fentanyl and it may be recommended as a better option when sedation is not desirable. When some amount of sedation is acceptable or required addition of $60 \mu \mathrm{g}$ of clonidine which gives excellent analgesia with negligible haemodynamic complications may be recommended.

\section{References}

1. Prakash S, Joshi N, Gogia AR, Prakash S, Singh R. Analgesic efficacy of two doses of intrathecal Midazolam with bupivacaine in patients undergoing cesarean delivery. Regional Anesthesia and Pain Medicine 2006; 31(3):221-226. PMid:16701187

2. Benhamou D, Thorin D, Brichant JF, Dailland P, Milon D, Schneider M. Intrathecal clonidine and fentanyl with hyperbaric bupivacaine improves analgesia during cesarean section. AnesthAnalg 1998;87(3):609-13.

PMid:9728839

3. Lavand'homme PM, Roelants F, Waterloos H, Collet V, De Kock MF. An evaluation of the postoperative antihyperalgesic and analgesic effects of intrathecal clonidine administered during elective cesarean delivery. AnesthAnalg 2008;107(3):948-55.

http://dx.doi.org/10.1213/ane.0b013e31817f1595

PMid:18713912

4. van Tuijl I, van Klei WA, van der Werff DB, Kalkman CJ. The effect of addition of intrathecal clonidine to hyperbaric bupivacaine on postoperative pain and morphine requirements after Caesarean section: a randomized controlled trial. Br J Anaesth 2006;97(3):365-70. http://dx.doi.org/10.1093/bja/ael182 PMid:16861258

5. Kothari N, Bogra J, Chaudhary AK. Evaluation of analgesic effects of intrathecal clonidine along with bupivacaine in cesarean section. Saudi J Anaesth2011;5(1):31-5. http://dx.doi.org/10.4103/1658-354X.76499 PMid:21655013 PMCid:PMC3101750

6. Bajwa SJ, Bajwa SK, Kaur J, Singh A, Singh A, Parmar SS. Prevention of hypotension and prolongation of postoperative analgesia in emergency cesarean sections: A randomized study with intrathecal clonidine. Int J Crit Illn Inj Sci 2012;2(2):63-9.

http://dx.doi.org/10.4103/2229-5151.97269

PMid:22837893 PMCid:PMC3401819

7. Wang C, Chakrabarti MK, Whitwam JG. Specific enhancement by fentanyl of the effects of intrathecal bupivacaine on nociceptive afferent but 
not on sympathetic efferent pathways in dogs. Anesthesia 1993; 79: 766-73. http://dx.doi.org/10.1097/00000542-19931000000019

8. Wang JK, Nauss LA, Thomas JE. Pain relief by intrathecally applied morphine in man. Anesthesiology 1979; 50: 149-51. http://dx.doi.org/10.1097/00000542-19790200000013

PMid:373503

9. Selvaraju KN, Sharma SV. Comparison of forced expiratory spirometric flow changes following intrathecal bupivacaine and bupivacaine with fentanyl. SAJAA 2008; 14(5): 33-37.

10. DeKock M. Site of hemodynamic effects of alpha subs 2 adrenergic agonists. Anaesthesiology 1991;75:715-6.

http://dx.doi.org/10.1097/00000542-199110000$\underline{00046}$

11. Bonnet F, B.V, Francois Y, et al. Effects of oral and subarachnoid clonidine on spinal anesthesia with bupivacaine. RegAnesth 1990; 15:211-4. PMid:2073488

12. Sethi BS, Mary Samuel, Deepak Sreevastava. Efficacy of Analgesic Effects of Low Dose Intrathecal Clonidine as Adjuvant to Bupivacaine.Indian J Anaesth 2007; 51 (5) : 41519

13. Shah BB, Shidhaye RV, Divekar DS, Panditrao M, Panditrao MM, Suryawanshi C. Effect of addition of Clonidine to Bupivacaine used for patients undergoing spinal anaesthesia: A randomized, double blind, controlled study. Sri Lankan Journal of Anaesthesiology 2011; 19(1):17-21 http://dx.doi.org/10.4038/slja.v19i1.1715

14. Biswas BN, Rudra A, Bose BK, Nath S, Chakrabarty S, Bhattacharjee S. Intrathecal fentanyl with hyperbaric bupivacaine improves analgesia during caesarean delivery and in early post operative period. Indian $\mathrm{J}$ Anaesth 2002;46(6):469-472.

15. Breen TW, Shapiro T, Glass B, Foster-Payne D, Oriol NE. Epidural anesthesia for labor in an ambulatory patient. AnesthAnalg. 1993; 77:919-24. http://dx.doi.org/10.1213/00000539-19931100000008

PMid:8214727

16. Agrawal A, Agrawal S, Asthana V, Payal YS, Sharma J, Gupta V. Comparison of intrathecal fentanyl and Sufentanil in addition to bupivacaine for caesarean section under spinal anaesthesia. J AnaesthClinPharmacol 2009;25(2):154-56.

17. Elia N, Culebras X, Mazza C, Schiffer E, Tramèr MR. Clonidine as an adjuvant to intrathecal local anesthetics for surgery: systematic review of randomized trials. RegAnesth Pain Med.
2008;33(2):159-67.

PMid:18299097

18. Niemi L. Effects of intrathecal clonidine on duration of bupivacaine spinal anaesthesia, haemodynamics, and postoperative analgesia in patients undergoing knee arthroscopy. ActaAnaesthesiolScand 1994;38(7):724-8. http://dx.doi.org/10.1111/j.13996576.1994.tb03985.x PMid:7839785

19. Dahlgren G, Hultstrand C, Jakobsson J et al. Intrathecalsufentanil, fentanyl or plaecebo added to bupivacaine for caesarean section. AnesthAnalg 1997;85:1288-93.

PMid:9390596

20. Hunt CO, Naulty JS, Bader AM et al. Perioperative analgesia with subarchnoid fentanyl bupivacaine for Caesarean delivery. Anesthesiology 1989;71:535-40. http://dx.doi.org/10.1097/00000542-198910000$\underline{00009}$

PMid:2679237 